\title{
Sana'a, Structure, Historical Form, Architecture and Culture
}

\author{
Hossein Soltanzadeh, Mohammadreza Sadeghi Moghaddam*
}

Department of Urban Design \& Planning, Qazvin Branch, Islamic Azad University, Iran

Copyright (C) 2015 by authors, all rights reserved. Authors agree that this article remain permanently open access under the terms of the Creative Commons Attribution License 4.0 International License

\begin{abstract}
The historic city of Sana'a is an example of Islamic cities which is known as one of the most valuable historical city center of Islamic culture. In this regard, recognition of the structure and the historic city form of Sana'a, with emphasis on Islamic culture is analyzed and examined in this study. The important issue is that, the structures and architectural style of Islamic cities around the world, beside the common features, have difference and diversities which is also not recognized. The purpose of this study, is the recognition of the structure and form of the ancient city of Sana'a, with emphasis on Islamic culture. "What is the chief role of Islamic culture on the formation of Sana'a?" is the main question of this study. The theoretical framework of this study emphasizes on this fact that Islamic culture has played an important role in the organization of ancient cities. Descriptive-analytical method was selected which the independent and the dependent variables are the formation of Islamic culture in the city and important elements, respectively. Documentation and studying in the library are the best method for collecting data and data analyzing was don with examining the other documents such as drawings and related photographs to the different time intervals of urban spaces Sana'a. The results indicated that, the mosque, market and the other religious institutions have shaped the main axis of city culture and there's a close bilateral relations between the Islamic culture, the structure and the form of the ancient city of Sana'a.
\end{abstract}

Keywords Islamic City, Urban Form and Structure, Islamic Culture, Cultural Axis, Sana'a

\section{Introduction}

Yemen is a country which is located in Asia continent, is an Arab country in Southwest Asia, occupying the southwestern to southern end of the Arabian Peninsula and its capital is Sana'a. It is bordered by Saudi Arabia to the north, the Red Sea to the west, the Gulf of Aden and Arabian
Sea to the south, and Oman to the east. Yemen has several different natural islands [1].

Yemeni lands has at least three thousands history and because of ancient civilization in trade part was a link ring between India, China, Africa and the Mediterranean and it was one of the richest regions of the Old World[2].

The Old City of Sana'a is known world-wide as one of the most authentic and significant examples of the extraordinary urban civilization which developed in the Arabia Felix in the 2 nd century B.C. Since the 1970 s it has been the object of many studies by urban specialists, architects and historians, testifying to its outstanding heritage values, and pointing out the threats from the nascent and rapid modernization affecting its authenticity and integrity after many centuries of almost complete isolation. At the beginning of the 1980s a Campaign and an Action Plan to preserve the Old City were proposed by UNESCO, which were launched after its inscription on the World Heritage List in 1986[3].

Sana'a was capital of north of Yemen till 1990 (Arabian republic of Yemen) and after combining two parts of Yemen, was also selected as capital of Yemen. Sana'a is located in an upland basin at an altitude of 2300 meters within a mountainous and semi-arid region of Yemen. Because of its high altitude, the city enjoys a moderate climate year around. The main rainy season is in summer [4].

In addition to the political importance of Sana'a, it has also importance in commercial, economic and tourism and about more than half of Yemen's hotel is located in Sana'a and more than $30 \%$ of commercial and industrial areas of the country are located in the metropolitan area of Sana'a. Throughout the last two decades, the city has been experiencing a rapid population and urban growth. With an average $9-10 \%$ annual growth rate within the last three decades, the population has grown from 135,000 inhabitants in 1975 to more than 1.9 million in 2007 and it is expected that the population would be doubled in 20 years if the same growth rate would continue [5].

Because of valuable urban and urban development resources of Sana'a, it is known as a city with a high level of architectural and urban culture, which is cited in some published books and scientific articles. Studies indicate the 
existence of sidewalks, crossings, public transit and municipal water supply systems in the streets of the old city of Sana'a (UNESCO et al, 1987:6).

Being listed within the UNESCO world heritage sites, the municipality has great tourism potential which should be complemented with related economic and recreational activities such as revitalization of traditional handcrafts, open spaces, cultural centers, historical and eco-parks [5].

According to the above description and the main question of the study, which are related to the cultural role and evaluating its effect on the formation of Sana'a city and architecture. In this study, the historical process of Sana'a formation and the main urban spaces and architecture was studied at the first step and finally, the main cultural axis of Sana'a was identified with recognition of Sana's cultural reflection.

\section{Background Research}

Some few detailed studies have been conducted about Sana'a urbanization in Yemen and history of the city has only mentioned in some references, the most important references are mentioned as below:

Michel Lamperakos has pointed to the unique architecture of Sana'a in his article entitled "Review of Cultural History: Lessons from Sana'a, Yemen" And it is considered as an international heritage. Abdullah Al-Abed (2011) in his article entitled "Sana'a public transportation" has referred to the new and historical transportation system and he has recommended some suggestion to develop public transportation of Sana'a [6]. Madbully has pointed several suitable recommendations for better management of Sanaa in his report" urban planning and management in the Municipality of Sana'a" (2008). In this regard, the Urban Development Strategy Sana'a (2010) by Ahmed El Basti team also presented the vision and objectives for Sanaa management.

\section{Theoretical Framework}

Amos Rapoport believes that cultural factors, particularly religious beliefs of the people by creating human habitats have often been an objective manner symbol based on the cultural construction theory. Hillier also believes that the cultural structures, social, administrative and religious beliefs affected the settlements affected, and believes that cities have both symbolic and functional nature [7].

Krapof and Askari have noted specific identity role and sovereignty in the city physical form.

Hanson and Benevolo believe that physical form of house is affected by political control and the importance of confidentiality in terms of belief. Koneo focus also on the role of customs, culture and religious rituals on physical form of the city and the concept of Islamic city, not only in city form studies, but also in the structure of social and cultural studies and its relationship with the physical form of the city [8].

On the other hand, it can be stated that: Cities and biological complexes are the most tangible aspects of human culture. In addition of this type of communication, urban spaces are cultural and effective environment which can be an effective form of infrastructure and intellectual community. Islamic cities are no exception in these phenomena [9].

Finally, the overall physical form of Islamic city can be described as below: Islamic city, a city that is focused around the mosque and have a market and bathroom. Islamic city was divided to some neighborhood by the religious separation. The city has specific architecture and is surrounded around the mosque because of security reasons [10].

\section{Methodology}

The Methodology is the general research strategy that outlines the way in which a research project is to be undertaken and, among other things, identifies the methods to be used in it. In various sciences, different methods were used for studying to identify the specific subjects. Having a clear methodology is often deemed important, especially in the sciences. Clearly outlined directions and procedures tend to increase consistency, and to create work which can be repeated elsewhere, which is an important characteristic of rigorous scientific research. In this study, the type of research is application-development and the evaluation methods are analytic and descriptive. Method of gathering data is documentation and surveys in the library.

Culture is independent variable and the dependent variables in this study are how the formation of the city, architecture and culture axes.

\section{Results and Discussion}

\subsection{Examining the Historical City Formation Process}

The opportunities for undertaking serious research in the Yemen, and particularly in Sana'a, which began after the end of the Civil War, have been nowhere more significant than in architectural studies. Although only a limited time has passed since then, and architectural researchers are seriously handicapped by the lack of any archaeological study within or near the city, and by the absence of classification on most of the documentation, the immense wealth of surviving buildings in Sana'a has made it possible to establish the main outline of building development for at least the last 300 years, and, in the case of mosques, for well over a thousand years [11].

Many literatures piled up many reasons behind calling Sana'a with this name. It has been said that this naming due to quality of craft itself, and also it has been said that when it 
was occupied by Ethiopians who found it built by stones and fortified, they said that this is a craft that means "fortified", consequently, it called Sana'a [5].

The overall view of the old city of Sana'a can be easily concluded as bellow: The city is not formed randomly and unorganized and there's a specific planning and architecture in organization and formation of the buildings [12].The oldest map of Sana'a is related to the German tourist, journalist and mathematician Carsten Niebuhr (1733- 1815) A.D. In the middle of the year 1762/1176, Carsten Niebuhr went Yemen through the coast of the Red Sea bound. Niebuhr during his staying in Yemen has done several different review about it [13].

Figure 1 indicate Sana'a map which is drawn by Niebuhr in 1763 A.D.

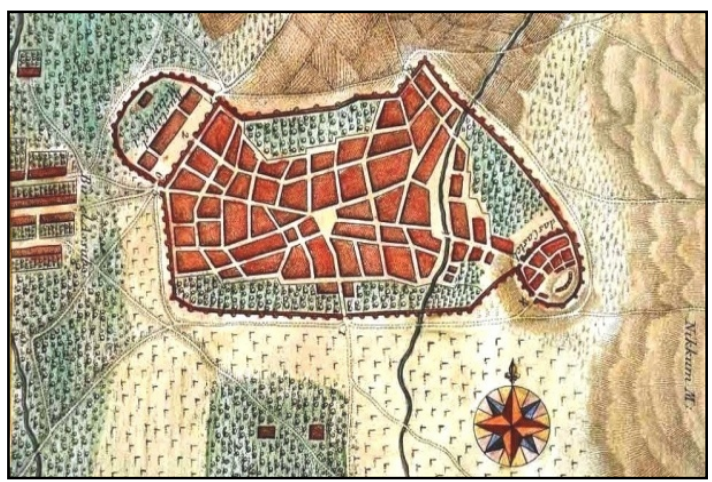

Figure 1. Sana'a map drawn by Niebuhr in 1763 [14]

There is a general ambiguity about the story of establishment of Sana'a because of different stories about its establishment, Some books described it as oldest city of the universe, while Arab references mentioned that the history of establishment of Sana'a goes back to the period after the so-called Tawafan (Cataract), They also mentioned that Sam Bin Noah was the first one who established it and built the palace of Ghamdan, and it called the city of Sam referring to the name of its founder. Therefore, man could say that Sana'a is considered as one of the ancient and oldest of the Arab cities that refer to Sabba'i and Humanities ages. The city of Sana'a was spontaneously established like other old cities on caravan roads that crossing from south to the north and not like the modern cities that planned and implemented in accordance with modern scientific means The historians of old cities believed that the city of Sana'a may started in a form of a house and then developed into a village and expanded throughout the phases of historical development of Yemen. The palace of Ghamdan represents one of the prominent stages of development of the city of Sana'a. It considered as the first kernel of the city, and it constituted another urban settlement that allows the establishment of more buildings [5].

In different Islamic periods, Sana'a architecture context has been maintained which cause the importance of it to be one of Universal cultural heritage. Although the ancient palace which was built before Islam had been destroyed but their reconstruction in different periods has been continued in different periods. Hence, the original shape and characteristics of the city has been related to the old principles [15].

Figure 2 shows the map of Sana'a in the 1940s that the first nucleus of the ancient city of Sana'a is indicated by the fence.

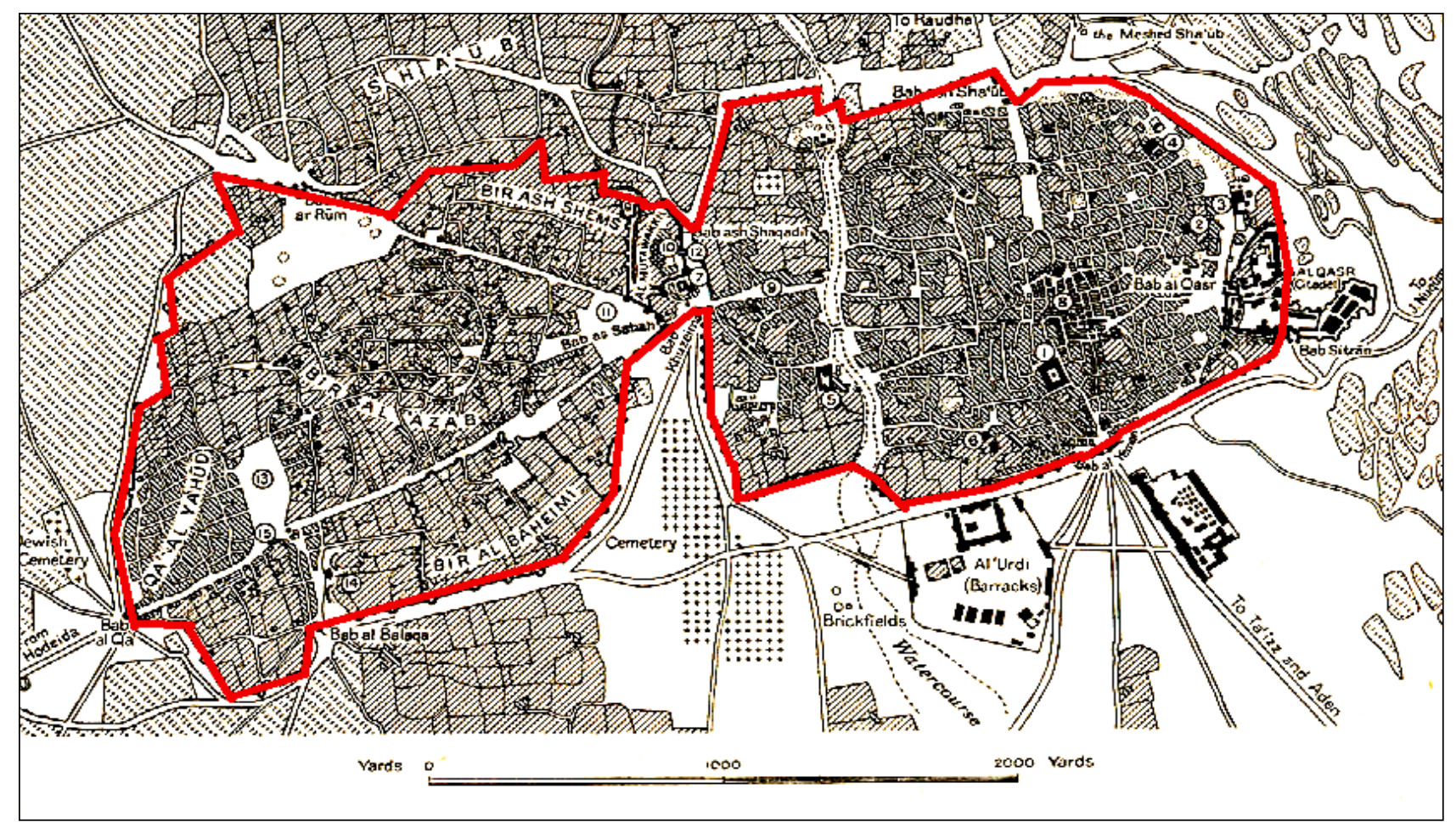

Figure 2. Sana'a map in the 1940s [4] 
Existence a variety forms in the design of structures in the old city of Sana'a as a variety of shapes such as circles, squares and rectangles, and also using other materials such as stone, brick buildings described the rich Islamic architecture and culture of this historical city [16].

The presence of Islam in Yemen, Islamic symbols such as mosques, baths, markets and specific architecture of Sana'a were expanded and cause to have a special prosperous in economic and architectural prosperous.

Features of First Kernel of the City of Sana'a:

- The old city characterized by its Yemeni unique style, and the features of Islamic style appeared in schools and mosques.

- The city looks as one structure.

- It characterized by its circular planning that harmonizes with the nature of Islamic cities.

- It is fine city and highly populated, and it also characterized by vitality and activity.

- It characterized by its narrow roads.

- It covers an area of 156 hectares [5].

Residential neighborhood in Sana'a is the largest part of the city in term of quantity and quality functional space. Each neighborhood has communication paths, streets and open spaces of their own and other neighborhoods linked by paths. Residential neighborhoods in the city of Sana'a are human scale that reflects the religious values of the Islamic community.

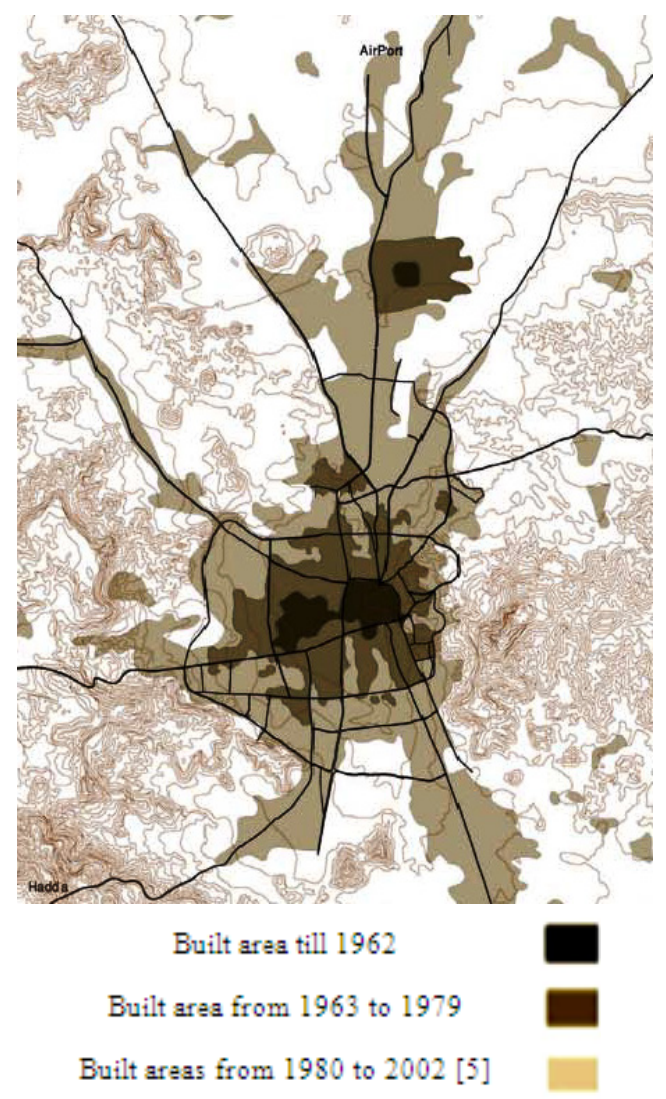

Figure 3. Sana'a historical revolution
After the revolution in $26^{\text {th }}$ Sept. $1962 / 1382$, Sana'a has been the emergence of modern urban development. And Yemen opened the door to the foreign international relations. Since having sufficient accommodation, Sana'a was in fluxed by the other neighborhood immigrants. As it is shown in Fig.3, Sana'a has had a large prosperous in the range of 1963-1979 and 1980-2002 in residential and commercial areas [17].

\subsection{Spaces and Urban Elements}

\subsubsection{Castle, fences and gates}

\subsubsection{Castle}

In Sana'a, there's an elegance castle, named Ghamdan which was broke down and rebuilt again several times during raid of Habashian to Yemen [18]. Coronation of Yemen king was in Ghamdan castle till Osman ebn Afan but it was destroyed by the order of him [19].

\subsubsection{Fences and gates}

Military fortifications around the city is made up of three components

1. The main wall

2. Gate (Bab), which was in the path of the main streets of the city link to external destinations.

3 . The defense towers [20].

The first kernel of old Sana'a was in the castle fence and walls. The fence and the wall of the city have defensive roles to improve security and strengthen of the city. In the fourth century $\mathrm{AD}$, the bricked walls were added to the natural defenses of Sana'a [21]. (See Fig. 4)

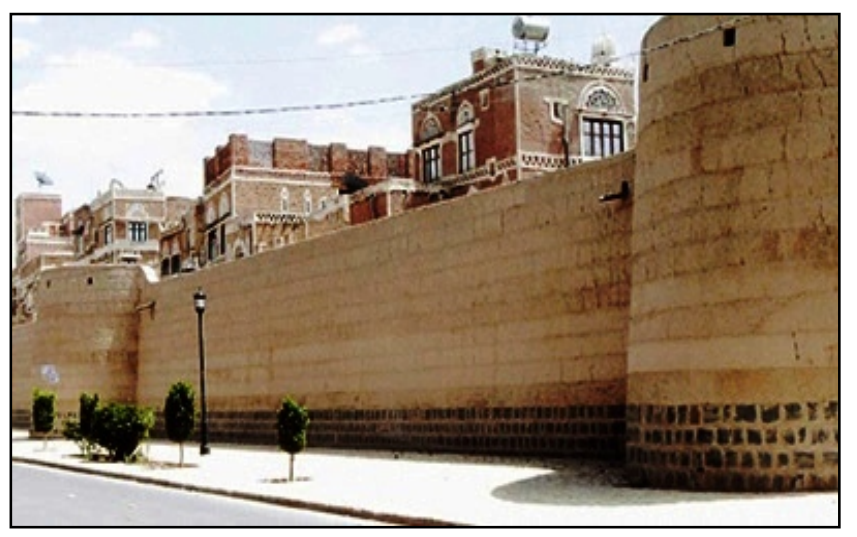

Figure 4. The old fence of Sana'a [22]

There are several different gates in Sana'a in order to entrance, existence, commercial, economics and cultural interactions to the other communities.

Yemen tourism union has been site that historical wall of Yemen is impenetrable from four main gates, as bellows:

1. Yemen gates: is the south gate of Yemen. Yemen gates in 1950 is shown in Figure 5. 


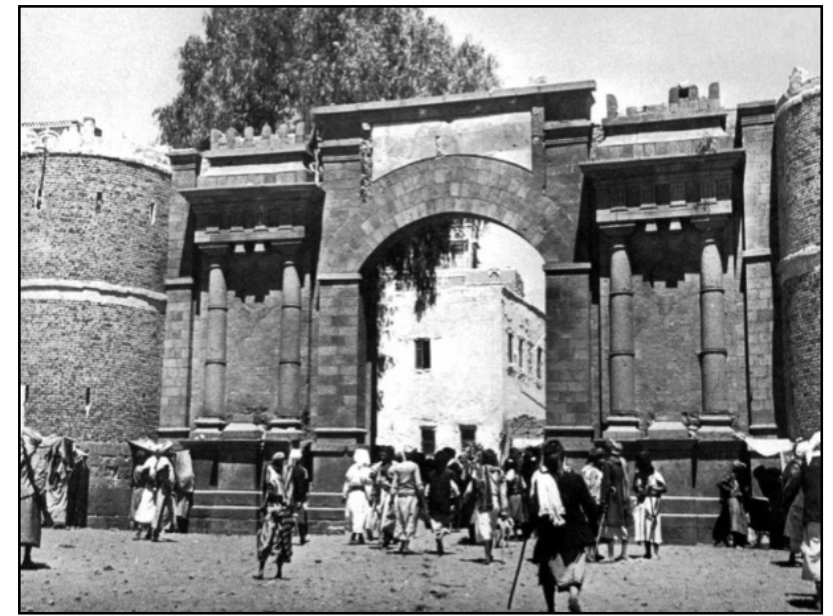

Figure 5. Yemen gates in 1950s [23]

2. Shaub gate: is the north gate of the city (See Fig.6).

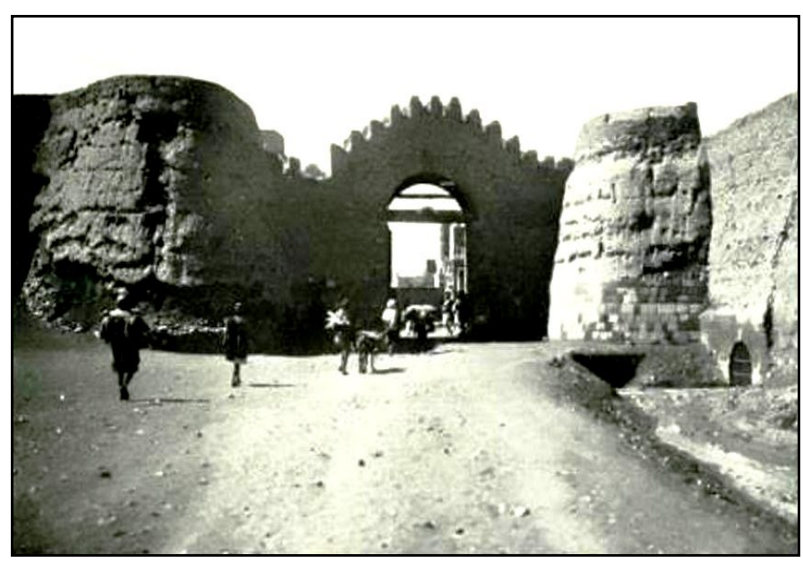

Figure 6. The old fence and Shaub gate of Sana'a in 1950s [23]

3. Setran gate: is the East gate of Sana'a

4. Sobheh gate: is the west gate of the city

The secondary gates of Sana'a are:

1. Khazimeh gates

2. Shaghadif gates

3. Balgheh gate

4. Rom gate

5. Ghae gate [24]

Yemen gate has several different functional and application such as: domestic market, a place for gathering citizens for special events and occasions (See Fig.7\&8).

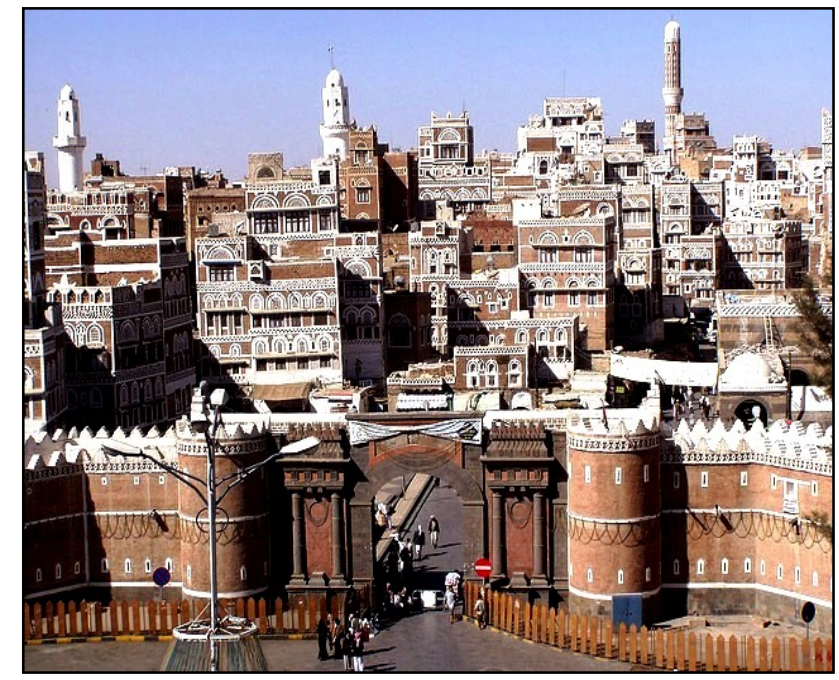

Figure 7. Yemen gate in the current days [24].

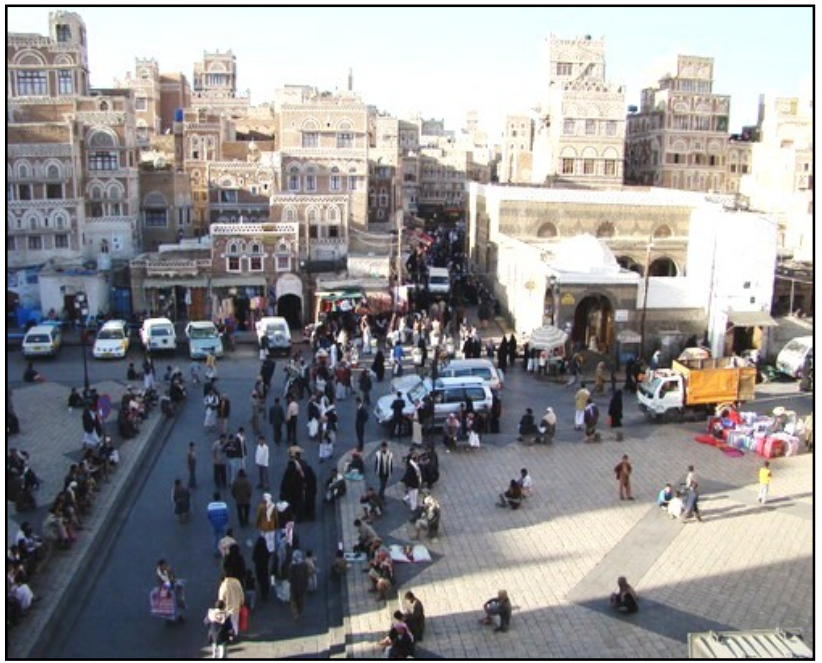

Figure 8. Citizen gathering in urban spaces of Yemen gate [24]

\subsubsection{Market}

Suq is a place for the supply of the goods. Suq is the name of the market or the street which contain markets. Suq is used before the name of the goods (are not sold). Urban cohesion, growth and market features have a unique role in the urban development. One of the most important features of the Islamic market system is job classification. It is related to their status of the mosque [20]. The old market is indicated in Figure 9. 


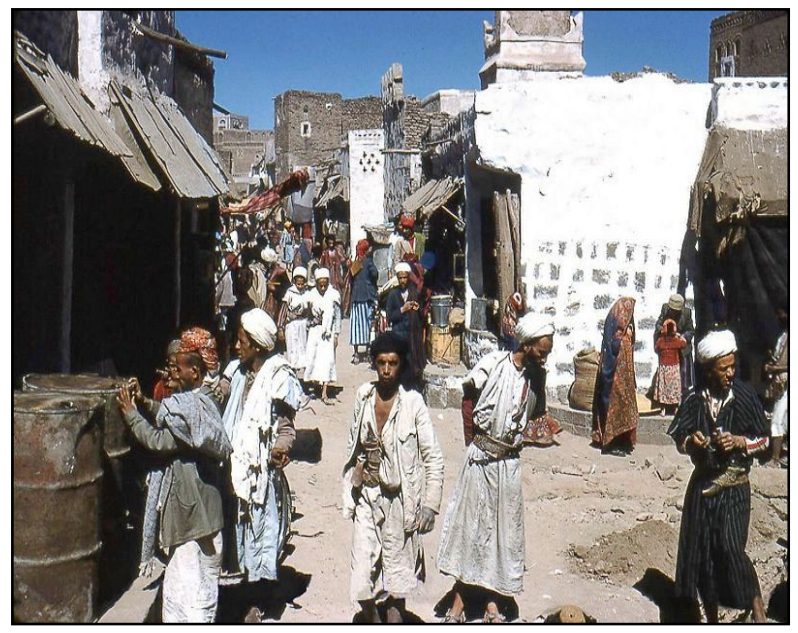

Figure 9. The old Sana'a market (1958) [21].

Next to the Great Mosque of Sana'a, there are a network of markets, commercial centers and street. This issue suggests that a city connection is associated with spiritual matters. Figure 10 shows the old market in 2013.

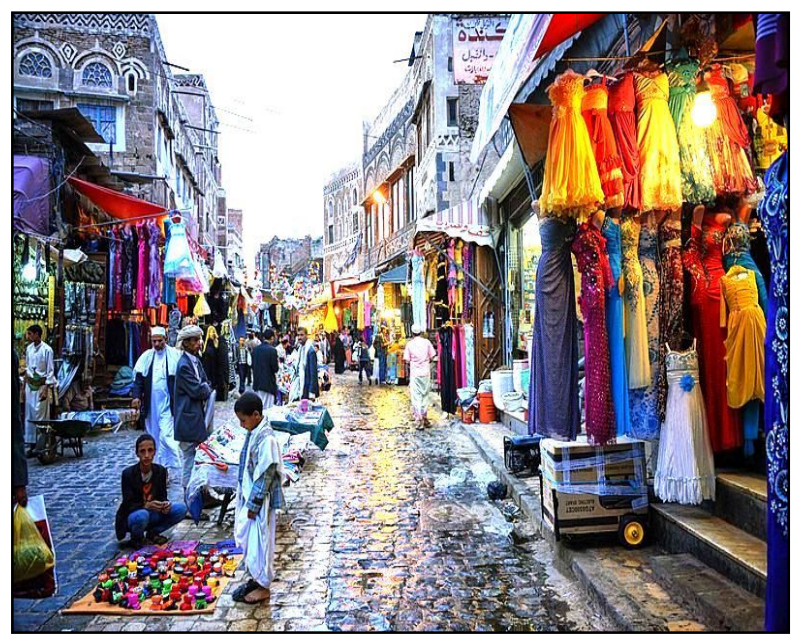

Figure10. The old Sana'a market (2013) [24]

\subsection{Spaces and Architecture Elements}

\subsubsection{Mosque}

There are several mosques in Sana'a, which all of them are known as national monuments (Lewcock, 1987:4).

The most important and the biggest building of old Sana'a was Alkabir mosque. Maz ebn Jabal, who was sent to Yemen, built it according to prophet Mohammad design and order in the 6th of A.H. Sana'a mosque which was built in the first century of A.H., is rectangular and it is the third largest mosque in the world, after prophet Mohammad and Ghaba mosque. Two special columns of the mosque which are named Masmureh and Manghure with the old sanctuary and the other four columns indicate the location of the mosque. Another mosque columns with various sections are given from the destroying parts of the Ghamdan palace which was formed the porch and the other subsequent development.
There's a stone cube-shaped building in the middle of mosque country yard which evokes "Kaebeh". The two minarets were built on the East and West part of the mosque [15].

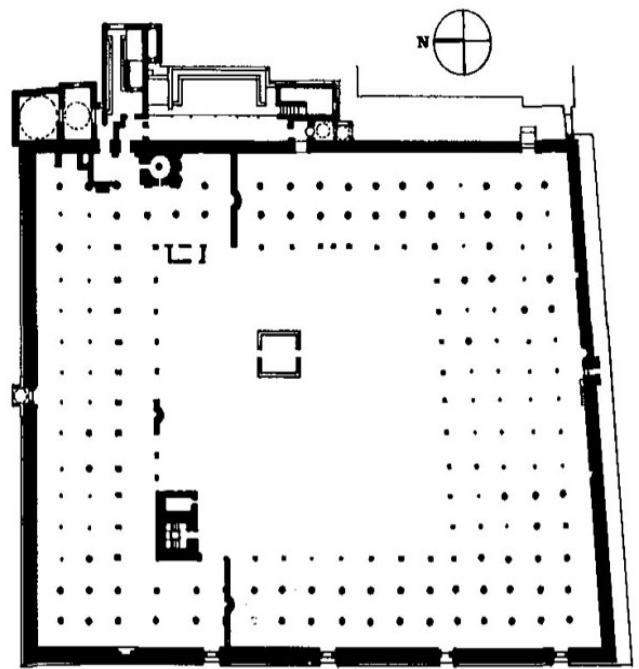

Figure 11. The plan of Sana'a mosque [25]

It is an excellent example of the unique architecture of the period. The big central country yard of the mosque is surrounded by prayer hall which its arch was built a simple stone. Figure.11 and 12 show the plan and the picture of Sana'a mosque.

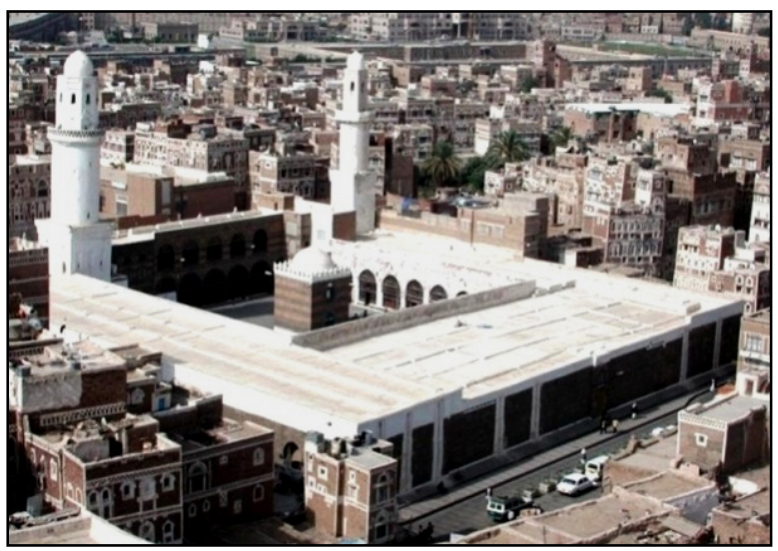

Figure 12. Sana'a mosque [26]

\subsubsection{House}

\subsubsection{Morphology of Yemen traditional house}

Yemeni architecture, with its distinguished features, is not a new phenomenon - it has a long history dating back to centuries before Islam. Yemen houses have several floors, which each of them has a special application. Since the unique architecture of Sana'a, it was selected as cultural capital of Arab world.

Yemeni architecture can be classified as follows:

- Houses built from local stones, as in Taizz, the villages of Al-Mahwit, Hajjah and Rema.

- Houses built from bricks. This type can be seen in busy 
cities, such as San'a, Sa'dah and Zabid.

- Houses made of compressed mud, such as in Al-Bayda and Sayun. houses with up to six stories.

- Houses built from mud, as in Hadramawt, Al-Muhrah, Hudaydah and Abyan.

- Houses made of wood, reed and straw.

- Tents made of goat skin, as in Ma'rib, Al-Jawf and Hadramawt.

These different types, materials and construction methods depend on the availability of materials and the climate [27].

\subsubsection{Sana'a house architectural styles}

There are three architecture styles for three different social classes of people. The eastern part of Sana'a is the largest part of the city which is devoted to the public house and there are a lot of mosques and markets in this area. Palace and gardens are located in the central part of the city. The western part of the city is for Jewish which is separated from the other two parts with two special gates. There are eight and nine floor building in this city but the average building floor is about five [7]. Figure 13 shows Sana's house which is drawn by Nibur.

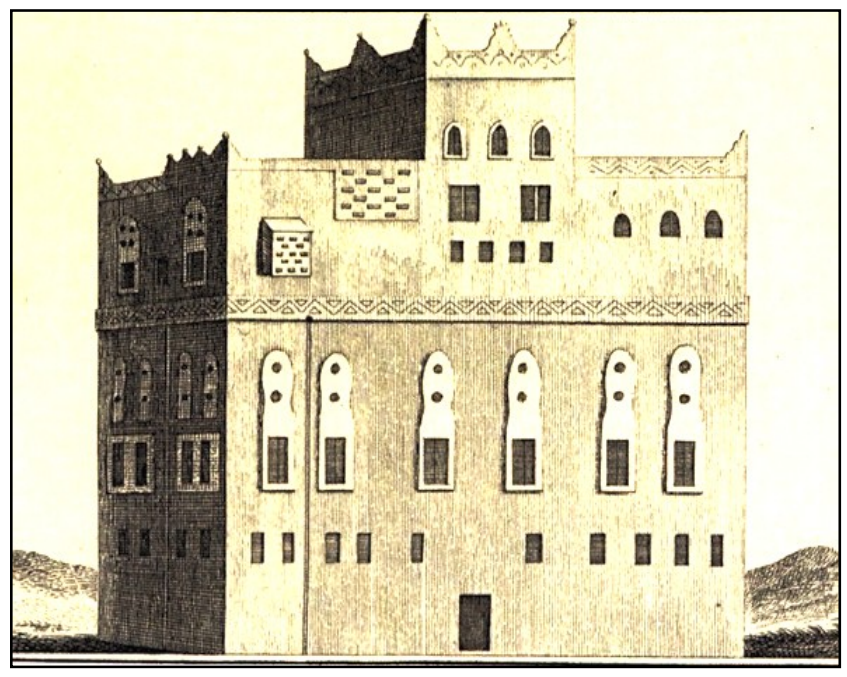

Figure 13. Sana'a house is drawn by Nibur in 1763 A.D. [23]

\subsubsection{Yemen building materials}

Buildings of all shapes - circular, rectangular and square rise out of the flat highland plain to seemingly impossible heights in apparently frail materials. The stonework of the lower levels may be rough rubble with loose mortar, but for most of their height the buildings are of mud, eroded by the monsoon rains until deep indentations mark the channels down which the autumnal torrents run to the ground. Sometimes a building is so weathered that in places the whole thickness of the wall is revealed, and eventually it has been abandoned. But the ruin survives to its full height for decades, reflecting the centuries of accumulated knowledge that under-lie its strength permanence. The houses may be square or circular towers culminating at the top in rectangular rooms crazily cantilevered beyond the walls
[28].

To building the traditional places in Yemen, local materials such as baked bricks, stones and dried flowers have been used. Mud and stone are usually used for the lower classes of the building and for the higher class, baked bricks is more often applied which is exactly related to Yemenis thinking way. Since stone is abundant in Yemen, it is used a lot in their building and it shows power, strength and stability of the building construction in Yemen. The applied stones in Yemen buildings have specific characteristics as bellow:

1 . Wide range variety color of stones are usually applied for the lower class of the building.

2. High resistance to moisture and water penetration into the building

3. Resistant to climate change

4. The ability to change its shape and form during construction [29].

\subsubsection{Sana'a traditional house details}

Sana'a houses could be divided in to three different groups:

1. Six floor houses (tower house)

2. Four floor houses (Turkish house)

3. Three floor houses (Jewish house) [30].

The typical house in Sana'a is called the 'tower house', which according to Varanda and others, probably evolved from the watch-tower. It is built using earth, stone, baked brick, or a combination of these materials with an interior staircase that allows vertical expansion as more space is needed. The house is notably narrow in relation to its height. Structurally, as Lewcock notes, the bedecked houses from five to nine storeys high are held together by the strength of the single staircase. They are generally occupied by a single family. According to Lewcock, the average number of people living in such a house is seven. The typical house of Sana'a is structured vertically [31].

The old houses in some areas can be seen that some families even two or three families close together, live together in a house. In some cases, a house is owned a sheikh and he is allocated it for the tribe members [32] (See Fig.14-17).

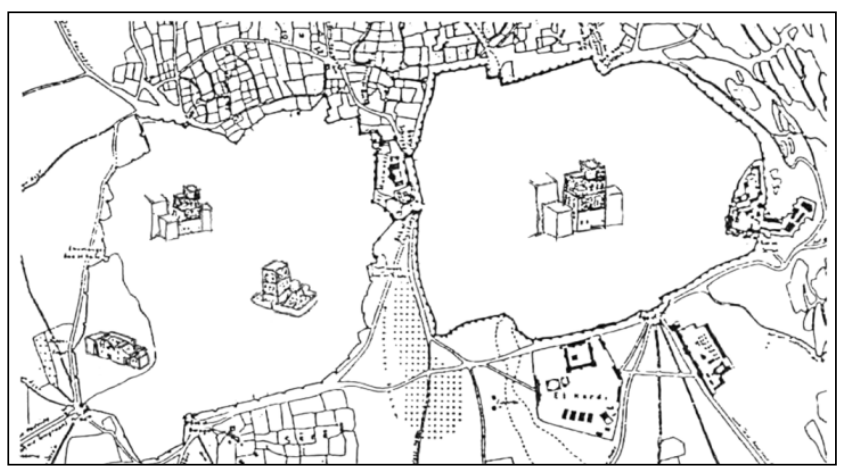

Figure 14. Different kinds of houses in Sana'a [30]. 


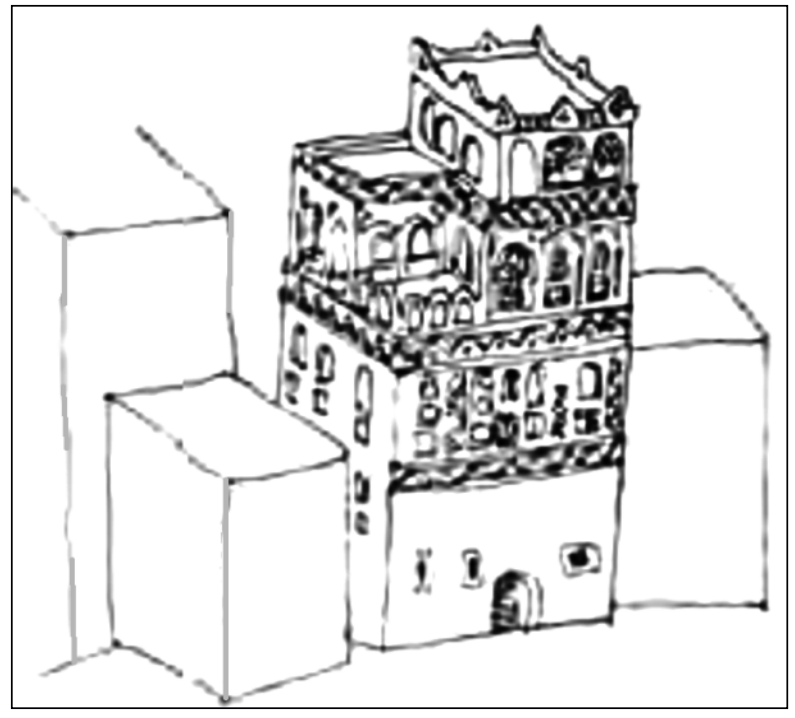

Figure 15. Tower house [30]

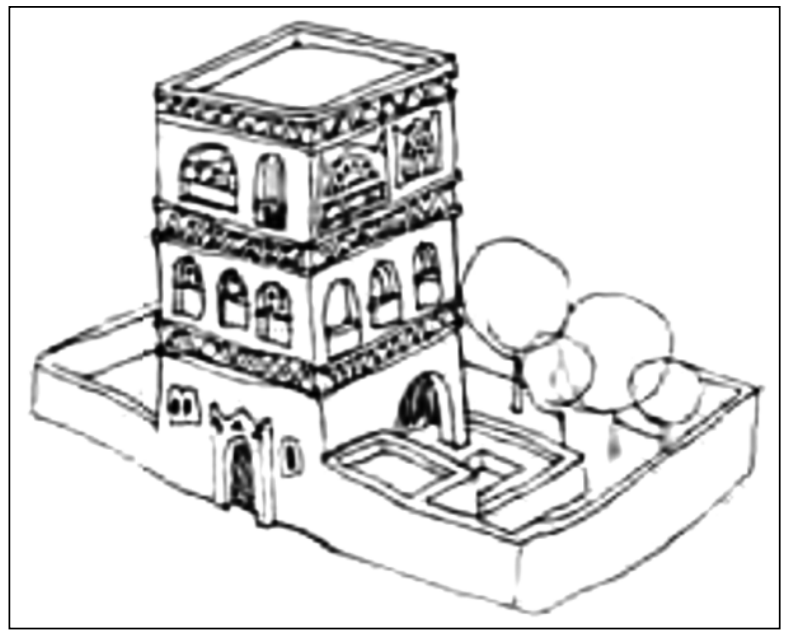

Figure 16.. Turkish house [30]

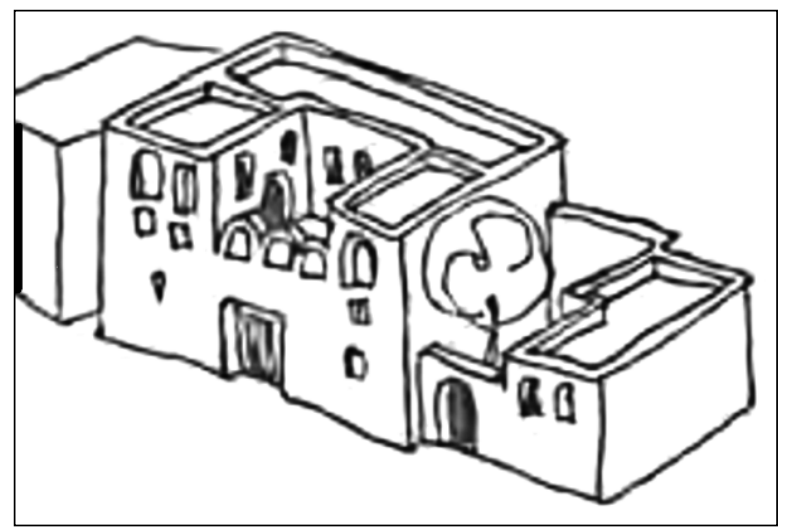

Figure 17. Jewedish house [30]

The stones are decorated the interior and exterior of the building. Some higher classes of the building are built by brick, gypsum and limestone. The interior walls of the buildings are whiten by gypsum and lime and are decorated with chalk and special designs. Entrance doors of the buildings are usually short and are simple decorated. The windows are wooden. Skylights plaster with colored glass and special designs are embedded which is named Ghamaryeh [15].

Fig.18 shows a sample of Ghamaryeh in Yemen house.

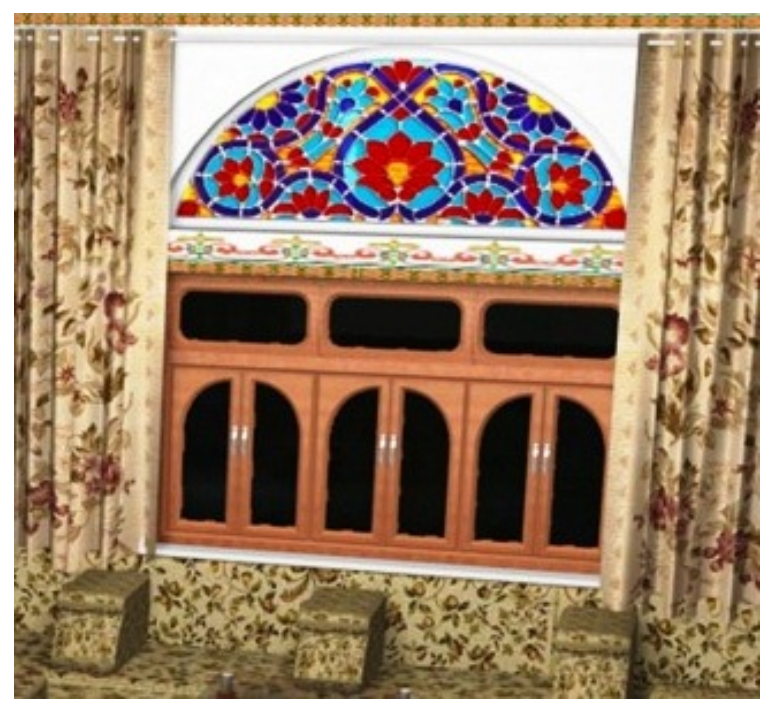

Figure 18. Ghamaryeh in Sana'a traditional house

The section of Sana'a public house is shown in Fig.19

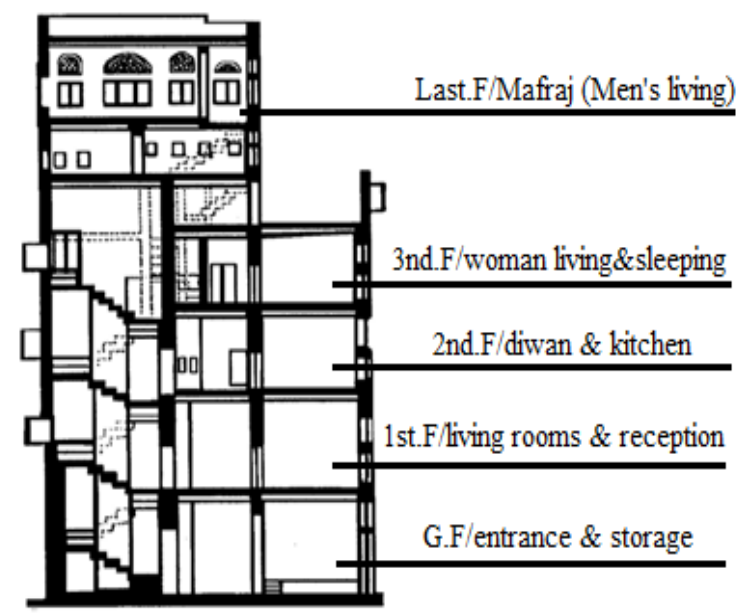

Figure 19. The application of Sana'a house floors [31].

In the ground floor there is the entrance hall, or (dihliz) with store rooms, and stables for house animals. In the first floor there is the biggest room used for family gatherings and for reception of well intentioned visitors; it is spread with carpets and mats, and one may enter only after removing one's shoes. On the floor along the walls are cushions for sitting on, stuffed with cotton, lighter cushions are also provided so that people can rest their backs and heads against the wall and windows are low so that the seated people can look through [11]

On the second floor is the diwan where family celebrates weddings, births, and religious festivals. The third floor contains smaller rooms for women and children, as well as the kitchen in some houses or, according to Lewcock, can be 
in the second floor in others this floor is traditionally called the harem (from haram means 'forbidden') where men who are not close family members may not enter. On the upper floor on the flat roof is the mafraj, or men's living, where the householder retires alone or with friends, to smoke a water pipe and chew qat. The mafraj has colored windows on three sides to enjoy the views However, in large houses; room use frequently changes according to the season, allowing people to sleep in the coolest rooms in summer [31].

Al-mafraj is located at the top of Yemenis house. It has three sides window with various colors which provide a extraordinary breadth vision in the afternoon [25].

Skis design of Sana'a is indicated in Fig. 20.

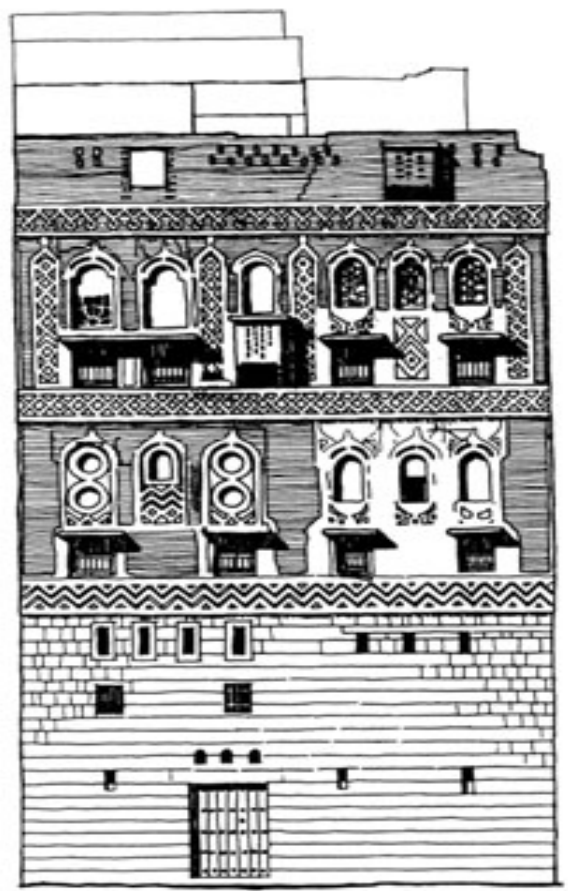

Figure 20. The conventional view of Sana'a building [30].

\section{Culture Reflection in Sana'a}

A city is a reflection of Islamic values as the view point of sponsors and residents. In addition of a variety, Islamic cities have the same features and present a certain form of the architecture. Since the Islamic beliefs, there's a strong network of Islamic culture in each part of the city [31].

The impact of Islamic thought and culture in the fabric of the city and people of Yemen and Sana'a has been seen. Ceremonies of this region are the most obvious effects of the country's Islamic culture.

\subsection{Islamic Ceremonies}

Yemenis are becoming together in a certain days of the year because of the Islamic beliefs. The most important of Yemen's Islamic ceremonies are presented in table.1

As shown in Table 1, all the ceremonies are based on
Islamic culture and have a high sanctity.

Table 1. Sana'a Islamic ceremonies [1]

\begin{tabular}{|c|c|c|c|}
\hline NO & Date & Event & Description \\
\hline 1 & 1 Moharram & $\begin{array}{c}\text { Immigration } \\
\text { anniversary of } \\
\text { Prophet Muhammad }\end{array}$ & $\begin{array}{c}\text { The first day of the } \\
\text { year (the Islamic } \\
\text { calendar) }\end{array}$ \\
\hline 2 & $\begin{array}{c}\text { From 29th } \\
\text { Ramezan-3 } \\
\text { Shaval }\end{array}$ & Fetr Eid & $\begin{array}{c}\text { Fasting after } \\
\text { Ramezan }\end{array}$ \\
\hline 3 & $9-13$ Zihajeh & Ghorban Eid & Hajj in Islam \\
\hline 4 & 27 th Rajab & $\begin{array}{c}\text { Ascension and the } \\
\text { Night of Destiny }\end{array}$ & - \\
\hline 5 & $\begin{array}{c}\text { 12th Rabieo } \\
\text { alaval }\end{array}$ & $\begin{array}{c}\text { Birthday of the } \\
\text { Prophet Muhammad }\end{array}$ & - \\
\hline
\end{tabular}

\subsection{Great Mosque (Jami' al Kabir) and its Cultural Impact}

Mosque of Sana'a is one of the first mosques in the Muslim world which was built by the order of Muhammad prophet.

Calligraphy and decoration of the mosque which is the main feature of Islamic art and architecture are presented in Sana'a mosques. In addition of Islamic worship, various educational and cultural works are done, in Sana'a great mosque. There's a big libraries in Sana'a great mosque which is famous to great library. Education and interpretation of the Holy Quran is also done in this mosque. The mosque has long been the breeding ground of Islamic culture and education (See Fig.21).

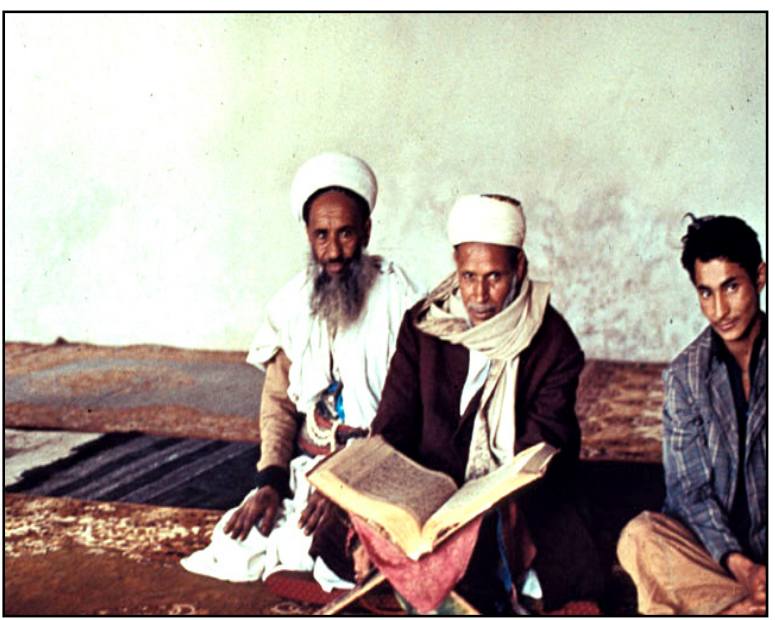

Figure 21. Teaching the holy Quran in great mosque of Sana'a

\subsection{Sana'a Cultural Axis}

Integration of cultural activities in the city center mosques and neighborhoods, Spatial-visual communication between city centers and compliance with all parts of the city center is one of the most prominent features of Islamic cities. According to the findings of historical studies in the fields of urbanism, architecture, social and cultural of Sana'a, it is clear that the city has a strong historical background. Form, 
shape, and its architecture is influenced by changes in different time periods. It is clear that the dramatic change in form, shape and architecture has been created in Sana'a by the arrival of Islam in the first century AD. All the activities are focused by the mosque, as the other Islamic cities. Mosque in the center of the manifestation of spiritual identity of Muslims that Islam has been considered as the most important element of architecture. Physical structure of Sana'a is not exception of this law, which way of communication the north and south of the main gate (Gate of Yemen and Shaub) located next to the Great Mosque of Sana'a and there's a main market of Sana'a, in the north east of it. Some mosques, schools and baths were built near these two city spaces. According to the above explanation and regular physical structure and hierarchy of the old city of Sana'a, a single cultural axis could be considered. The cultural axis was in the form of north-south axis which Yemen and Shaub gates are located at the beginning and the end of the axis. The great mosque and the main market of Sana'a are the main cultural elements, which are supported with the other mosques and schools. Physical elements of Sana' a cultural axis were discussed in Table 2 and are shown in Figure 22.
Table 2. Sana'a the main cultural elements

\begin{tabular}{|c|c|c|c|c|}
\hline $\begin{array}{c}\text { Location } \\
\text { relative to } \\
\text { cultural } \\
\text { axis }\end{array}$ & $\begin{array}{c}\text { Location } \\
\text { relative to } \\
\text { the street }\end{array}$ & Location & $\begin{array}{c}\text { Structural } \\
\text { form }\end{array}$ & $\begin{array}{c}\text { Physical } \\
\text { elements }\end{array}$ \\
\hline $\begin{array}{c}\text { Beginning } \\
\text { and end of } \\
\text { the } \\
\text { cultural }\end{array}$ & $\begin{array}{c}\text { At the } \\
\text { entrance of } \\
\text { the main } \\
\text { stree path }\end{array}$ & $\begin{array}{c}\text { Inscribed on } \\
\text { the wall of } \\
\text { the city, } \\
\text { often in } \\
\text { areas } \\
\text { overlooking } \\
\text { the city }\end{array}$ & $\begin{array}{c}\text { Taqy shaped } \\
\text { with } \\
\text { different } \\
\text { heights }\end{array}$ & $\begin{array}{c}\text { Gate } \\
\text { (Yemen } \\
\text { and } \\
\text { Shaub) }\end{array}$ \\
\hline $\begin{array}{c}\text { In the } \\
\text { vicinity of } \\
\text { the } \\
\text { culture }\end{array}$ & $\begin{array}{c}\text { Adjacent to } \\
\text { the main } \\
\text { thoroughfare } \\
\text { of the town }\end{array}$ & $\begin{array}{c}\text { Located in } \\
\text { the center } \\
\text { of the city }\end{array}$ & $\begin{array}{c}\text { Rectangular } \\
\text { shaped and } \\
\text { fits to } \\
\text { Ghebleh }\end{array}$ & $\begin{array}{c}\text { Sana'a } \\
\text { great } \\
\text { mosque }\end{array}$ \\
\hline $\begin{array}{c}\text { In the } \\
\text { context of } \\
\text { the } \\
\text { cultural } \\
\text { center }\end{array}$ & $\begin{array}{c}\text { Along the } \\
\text { main road }\end{array}$ & $\begin{array}{c}\text { In the } \\
\text { center of } \\
\text { the town } \\
\text { concentrated } \\
\text { in the } \\
\text { northeastern } \\
\text { mosque }\end{array}$ & $\begin{array}{c}\text { The } \\
\text { main } \\
\text { market }\end{array}$ \\
\hline
\end{tabular}

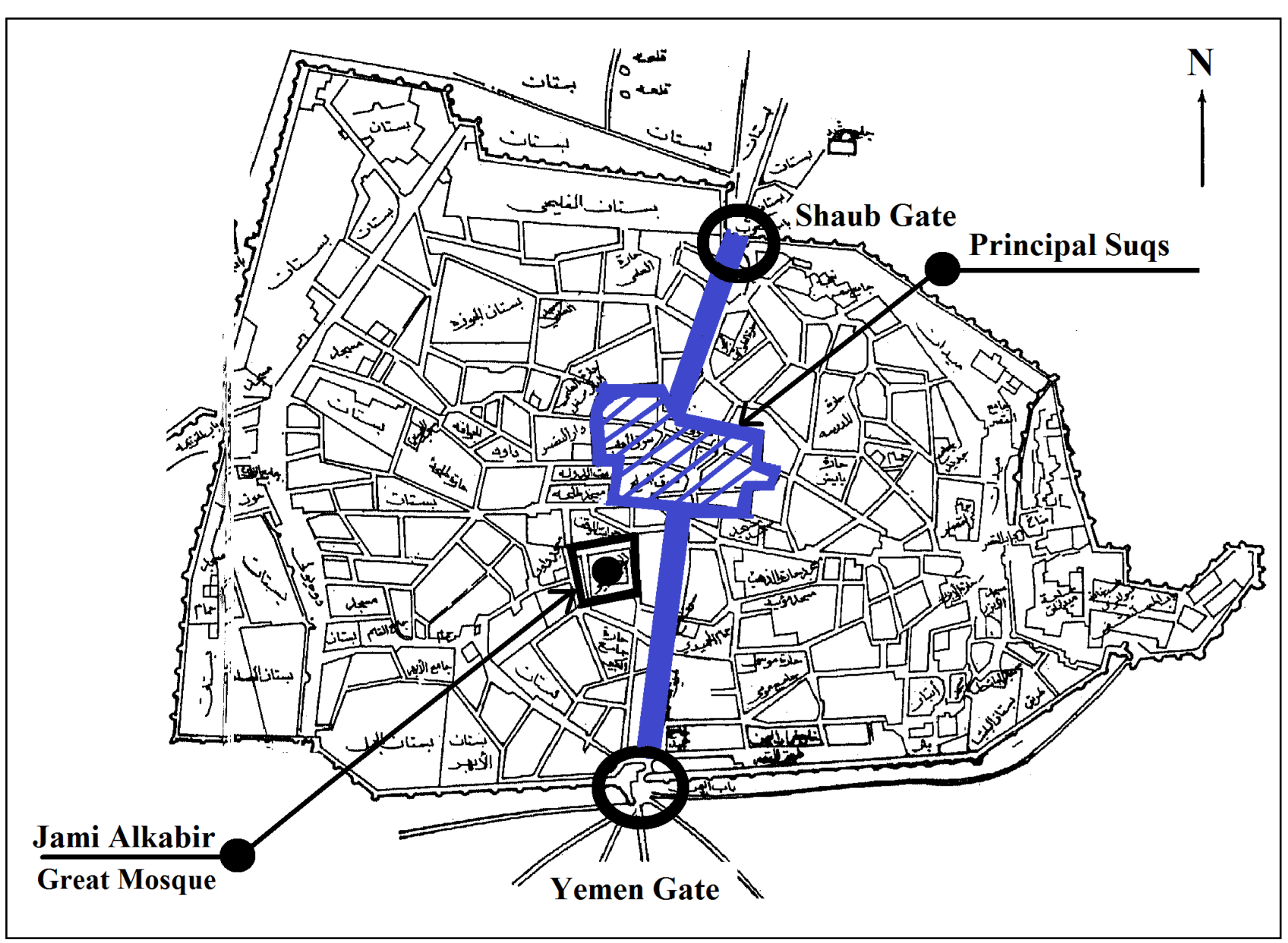

Figure 22. Sana'a cultural axis [1]. 


\section{Conclusions}

One of the best Islamic city compositions, with Islamic value and architecture, could be seen in Sana'a. Historical monuments such as Arg (Ghamdan castle), market, various schools and traditional composition of old houses are examples of Islamic architecture and values in Sana'a. The physical form of Sana'a is based on the regular crossing networks which are arrived to the main kernel of the city. The locations of urban and architectural elements are relative to the importance and application of them. The great mosque of Sana'a is located in the center of the city and market is next to it. The residential areas are so near to the market and have the major content of the city. Walls contain the main details of the city (great mosque, market and residential areas) and main crossing has connecting role in that city. The relative narrow alleys are connecting the other residential areas and the central elements of the areas. According to the above description which are indicated the physical form and the culture of Sana'a, two main points could be explained as the results of this study.

\section{1-Culture reflection in urbanism of Sana'a:}

One main cultural axis is formed in addition to the basic elements of Islamic cities such as, great mosque, market, schools, because of special beliefs of Yemenis which is affected by Islamic culture. It is connected the most important south gate of the city (Yemen gate) to the main north gate of the city (Shaub), and different kinds of activities are don in this rout.

\section{2-Special architecture of residential land use}

According to the different studies, it's obvious that architecture of residential land use of Sana'a is affected by the Islamic culture. Public and private spaces are separated exactly from each other because Islam focuses on Hejab. Existence of a special floor in Sana'a houses which devoted to the women is an example of this culture.

Totally, it can be said that Sana'a is designed and built based on Islamic culture theoretical framework, therefore its maintenance, protection and repair are the most important step of recovery of the city. To achieve those goals, motivate the citizens and inform them about the importance of Sana'a protection and repair. Urban management control and supervision have also an important role to achieve it.

\section{REFERENCES}

[1] www.yemen-nic.info

[2] A.R. Amirdehi, Land of the Islamic world : Yemen, ancient civilization from Sana'a to Aden's, The idea of approximation journal, Vol.21, 115-126, 1388.

[3] Pini.D, The inventory of the historic city of Sana'a A tool for urban conservation, UNESCO, UNESCO press, 2008.

[4] El Basti.A et al, Sana'a city development strategy, 2010.
[5] Madbouly.M, Urban Planning and Management in Sana'a Municipality, Cities Alliance Project Output, pp. 1-84, 2008.

[6] Al-Abed.A, SANA'A URBAN TRANSFORMATION: FROM WALLED TO FRAGMENTED CITY, Journal of Engineering Sciences, Assiut University, Vol. 39, No. 4, pp.897-918, 2011.

[7] R. Rahimi, Historic cities in the Muslim lands, recognition social, cultural and economic features in the form of (Case Istanbul ), Proceedings of the doctoral students of Islamic Azad University of Qazvin city, Chahar Tagh Ed, Tehran.

[8] M. Homafar, Recognize the role of cultural variables, social and economic construction and evolution of the city (Case Study : City of Dameshgh ), Proceedings of the PhD research Urban Azad University of Qazvin, Chahar tagh, Tehran, 1392.

[9] J. Danesh, Principles of formation and organization of the Islamic city, Journal of Islamic Iran, Vol.1, 15-31, 1389.

[10] N. Fatemi, Historic cities in the Muslim lands in the evolution of the physical exploration of Islamic Cairo, Proceedings of doctoral students of Islamic Azad University of Qazvin city, Chahar tagh Ed, Tehran, 1392.

[11] Lewcock. R, The old city of San'a, Development and urban Metamorphosis, Vol 1, pp 71-80, 1983.

[12] Almadhaji. M, Traditional Housing Neighborhoods: Urban Solutions and Modern Applications (Old Sana'a - A Case Study), Journal of Science \& Technology Vol. (12) No. (1), pp3-48, 2007.

[13] K. Nibour, Carsten Niebuhr travel, Tuka Ed, Tehran, 1354.

[14] http://alamree.net.

[15] A. Atri, Sana'a kabir mosque, the third Islamic world mosque, Foreign relationship journal, Vol.7\&8, 215-221, 1380 .

[16] Sevsenko.M.B, Adaptive reuse integrating traditional areas into the modern urban fabrics, the aga khan program for Islamic architecture at Harvard University and the masachusset institute of technology, 1983.

[17] http://whc.unesco.org

[18] Q. Gholestan, Architectural phenomenon on the eve of the formation of the Islamic community ( historic landscape ), Golestan Journal Quran, new period, Vol.36, 30-33, 1379.

[19] E. Shoshtari, A historic military campaigns of the Persian Gulf, Reviews of history, Vol. 5\&6, 69-88, 1345.

[20] B. Salim Hakim, Islamic Arab cities, the urbanization and construction , Ministry of Culture and Islamic Guidance , Tehran, 1381.

[21] Message from UNESCO, Pictures cultural building, Vol.219, 17-26, 1367.

[22] www. saadahpress.net

[23] http://alamree.net

[24] www.yemenat.net

[25] http://archnet.org

[26] www.whitr-ap.org 
[27] Al-Dhababi. K, Ancient civilization and magnificent heritage, Islamic Tourism journal, Issue 12, July-August, 54, 2004.

[28] Lewcock. R, The old city of San'a, Development and urban Metamorphosis, Vol 1, pp 71-80, 1983.

[29] http://shodhganga.inflibnet.ac.in

[30] A. Alghazali, The impact of technologies and Muar Banna new architecture local BeSana'a- Yemen, a letter of introduction to the Faculty of Engineering, University of Al-Azhar, 2005.
[31] Al Sayyed. W. THE MORPHOLOGY OF THE TRADITIONAL ARAB HOUSE, Examining courtyard and non-courtyard prototypes. Art \&Architecture Magazine London, Issue 10, pp 9-27, 2012.

[32] Lewcock. R, The old walled city of Sana'a, UNESCO, Printed in Belguim, ISBN 92-3-102362-4, pp 1-124, 1986.

[33] UNESCO et al, Conservation of Old Sana'a, Yemen, the Aga Khan Award for Architecture, pp 1-97, 1987.

[34] J. Danesh, Principles of formation and organization of the Islamic city, Journal of Islamic Iran, Vol.1, 15-31, 1389. 